\title{
BEBERAPA MENU SARAPAN MENGGUNAKAN PANGAN LOKAL TERHADAP PEMENUHAN KEBUTUHAN GIZI SISWA SEKOLAH DASAR
}

\author{
Henry S. Imbar ${ }^{1, a}$, Vera Harikedua ${ }^{2, a}$, Rivolta Walalangi ${ }^{3, a}$ \\ ${ }^{1}$ Jursan Gizi Poltekkes Kemenkes Manado Idonesia \\ ${ }^{\text {a }}$ PUI Poltekkes Kemenkes Manado \\ email korespondensi: hnrmbr@gmail.com
}

\begin{abstract}
;
Organoleptic testing is a test that is based on sensing process. Sensing can also mean mental reactions (sensation) if the senses receive stimuli (stimulus). Reaction or impression that is caused due to the stimulation may be an attitude to toward or away from, liking or disliking objects will cause stimulation.Formulation of the problem in this research is how the acceptance and preference level of primary school students towards some kind of breakfast menu using local food in North Sulawesi in order to fulfill nutritional needs. The general objective of this study is to make local food in North Sulawesi as a basic ingredient in making a breakfast menu with a variety favored by children in order to fulfill the nutritional needs of elementary school. The benefits of this research provide understanding to the community in particular who have children of primary school age that the fulfillment of nutrients on elementary school children is not always synonymous with foodstuffs are expensive, must be imported, instant, branded, but the quality and nutritional content is not very relevant to the needs child nutrition. This type of research is quasy Experiment was conducted in a laboratory study Culinary Nutrition Poltekkes Kemenkes Manado and Elementary School 06, which is located in Manado City. Collecting data in this study is the result of tests performed on the organoleptic properties, which consist of preference for appearance, flavor, texture, color and aroma.Hedonic data processing using Kruskal Wallis test showed no significant difference from the third menu tested.

Conclusion statistically no significant difference between the three breakfast menu with a conventional menu, but based on the average value of the hedonic score differences.
\end{abstract}

Key Words : Organoleptic. Breakfast Menu, Local Food, Elementary Student

\section{PENDAHULUAN}

Salah satu modal dasar pembangunan di Indonesia adalah Sumber Daya Manusia (SDM) yang potensial dan produktif. Keberhasilan pembangunan nasional suatu bangsa ditentukan oleh ketersediaan sumber daya manusia, yaitu SDM yang memiliki fisik yang tangguh, mental yang kuat dan kesehatan yang prima di samping penguasaan terhadap ilmu pengetahuan dan teknologi. Kekurangan gizi dapat merusak kualitas SDM (Departemen Kesehatan Republik Indonesia (Depkes RI, 2004a). Upaya peningkatan Sumber Daya Manusia diatur dalam Undang-Undang Dasar (UUD) 1945 pasal $28 \mathrm{H}$ ayat (1) yang menyatakan bahwa setiap individu berhak hidup sejahtera, dan pelayanan kesehatan adalah salah satu hak asasi manusia. Pemenuhan pangan dan gizi untuk kesehatan warga Negara merupakan investasi untuk peningkatan kualitas SDM (Depkes RI, 
2005). Syafruddin dkk. (2007) menyebutkan pangan merupakan kebutuhan dasar manusia. Pembangunan pangan kedepan dalam konteks otonomi daerah diharapkan mampu menyediakan pangan bagi penduduk terutama dari produksi dalam negeri, dalam jumlah dan keragaman yang cukup, aman dan terjangkau dari waktu ke waktu (sustainable).

Anak Usia sekolah sering tidak sarapan pagi karena berbagai sebab misalnya terburu-buru berangkat ke sekolah. Hasil penelitian Rampersaud et al. (2005) pada anak sekolah tahun di Amerika Serikat menunjukan bahwa sebesar $30 \%$ remaja tidak biasa sarapan pagi. Para anak yang tidak sarapan pagi biasanya menunda waktu sarapannya hingga jam istirahat tiba, karena itu kualitas gizi makanan jajanan yang dikonsumsi penting untuk diperhatikan.

Penelitian yang dilakukan Watanabe et al. (2005) di Vietnam menunjukkan bahwa peranan stimulasi dan intervensi gizi secara bersama-sama sangat penting dalam meningkatkan kemampuan kognitif anak-anak yang menderita gizi kurang. Anak-anak gizi kurang yang diberikan intervensi gizi dan stimulasi memiliki kemampuan kognitif yang lebih tinggi daripada anak yang hanya diberikan intervensi gizi saja.

Berbagai penelitian membuktikan bahwa makan pagi berpengaruh pada konsentrasi dan prestasi belajar anak sekolah Hasil penelitian Saidin (1991) pada anak sekolah dasar di kabupaten Bogor menunjukkan ada perbedaan yang nyata kemampuan konsentrasi menggunakan uji digit symbol antara anak yang biasa sarapan dengan yang tidak biasa sarapan. Hasil penelitian Kurniasari (2005) pada anak sekolah dasar di Yogyakarta menunjukkan ada hubungan yang nyata antara asupan energi makan pagi dengan konsentrasi di sekolah menggunakan uji digit symbol.

Hasil penelitian Sobaler, et al. (2003) pada 130 anak sekolah usia $6-13$ tahun di Madrid menunjukkan bahwa ada hubungan antara persentase asupan energi sarapan terhadap total energi dengan kemampuan intelektual anak.

Tujuan penelitian umum adalah menjadikan bahan pangan lokal yang ada di Sulawesi Utara sebagai bahan dasar dalam membuat menu breakfast dengan berbagai variasi yang disenangi oleh anak guna pemenuhan kebutuhan zat gizi anak sekolah dasar. Tujuan khusus yaitu mengembangkan resep-resep menu breakfast menggunakan pangan lokal yang tersedia dengan berbagai bentuk variasi menu dengan harga yang terjangkau oleh anak dari keluarga miskin; Analisis perbedaan organoleptik pangan lokal yang diolah dengan pangan konvensional; Membantu memenuhi kebutuhan zat gizi utama dan zat gizi khusus yang dapat meningkatkan konsentrasi belajar bahkan kecerdasan anak.

\section{BAHAN DAN CARA}

Jenis penelitian ini adalah quasy experiment, menggunakan rancangan statik eksperimen, penelitian ini dilaksanakan di Sekolah Dasar Negeri 06, yang terletak di pusat Kota Manado. Populasi dalam penelitian ini adalah seluruh anak Sekolah Dasar Negeri 06 yang memenuhi kriteria inklusi antara lain bisa membaca dan menulis, bersedia dan menandatangani inform consent, berada di tempat saat penelitian, kooperatif dan mengikuti proses penelitian sampai selesai. Sampel atau panelis dalam penelitian ini adalah anak-anak yang dipilih dengan menilai hasil dari instrumen pretest dimana semua anak yang bisa membaca dan menulis diberikan pertanyaan tertutup terkait dengan penilaian cita rasa (warna, 
rasa, aroma, tekstur, penampilan) menu breakfast. Pengumpulan data dalam penelitian ini adalah hasil dari pengujian yang dilakukan terhadap sifat organoleptik, yang meliputi uji kesukaan terhadap penampilan, citarasa, tekstur, warna dan aroma. Panelis ini terdiri dari siswa sekolah dasar yang bertugas menilai sifat atau mutu menu makanan berdasarkan kesan subjektif. Dalam penilaian organoleptik menu breakfast ini menggunakan panelis anak-anak. Panelis anak-anak adalah panelis yang khas menggunakan anak-anak berusia 712 tahun. Anak-anak ini digunakan sebagai panelis dalam penilaian menu breakfast yang disukai. Diganti panelis adalah Menu breakfast yang disajikan masing-masing dua jenis yaitu menu hasil modifikasi dan menu awal atau menu konvensional yang sudah sering dinikmati sehari-hari. Kemudian dilanjutkan dengan Uji kesukaan atau disebut uji hedonik diamana panelis dimintakan tanggapan pribadinya tentang kesukaan atau sebaliknya (ketidaksukaan). Di samping panelis mengemukakan tanggapan senang, suka atau kebalikannya, mereka juga mengemukakan tingkat kesukaannya. Panelis diberikan menu Paket A, Paket B dan Paket C. Tingkat-tingkat kesukaan ini disebut skala hedonik. Pengolahan dan analisis data diawali dengan melakukan editing, dan coding data untuk memudahkan proses pemasukan data kemudian dilanjutkan dengan mengentri data pada program software statistik, tahapan selanjutnya adalah melakukan Analisis data univariat (karakteristik dan distribusi frekuensi variabel) untuk mengetahui proporsi/distribusi dan karakteristik subjek penelitian, Hasil analisis dan interpretasi dan selanjutnya disajikan dalam bentuk tabel-dan narsi. Untuk mengetahui perbedaan antara menu breakfast konvensional dengan menu breakfast yang dimodivikasi menggunakan uji statistik Kruskal Wallis

\section{HASIL}

a. Karakteristik subjek penelitian

Penelitian ini dilaksanakan pada SD Neg 6 Kota Manado yang terletak di jalan Sarapung . Subjek penelitian berjumlah 36 orang terdiri dari 29 orang siswa kelas 5 dan 7 orang siswa kelas 6 . Dengan jenis kelamin terdiri dari laki-laki 14 orang siswa dan perempuan 22 orang siswa.

Karakteristik subjek penelitian berdasarkan jenis kelamin dan tingkatan kelas dapat dilihat pada tabel 1.

Tabel 1. Karakteristik Subjek Penelitian

\begin{tabular}{llll}
\hline Variabel & Kategori & $\mathrm{n}$ & $\%$ \\
\hline Jenis & Laki-laki & 14 & 39 \\
Kelamin & Perempuan & 22 & 61 \\
& Jumlah & 36 & 100 \\
\hline Kelas & Kelas 5 & 29 & 80 \\
& Kelas 6 & 7 & 20 \\
& Jumlah & 36 & 100 \\
\hline
\end{tabular}


b. Analisis kandungan zat gizi menu breakfast per porsi

Tabel 2. Analisis Kandungan Zat Gizi Per porsi

\begin{tabular}{ccccc}
\hline No & Zat Gizi per porsi & $\begin{array}{c}\text { Menu } \\
\text { Paket A }\end{array}$ & $\begin{array}{c}\text { Menu } \\
\text { Paket B }\end{array}$ & $\begin{array}{c}\text { Menu } \\
\text { Paket C }\end{array}$ \\
\hline 1 & Energi (Kkal) & 399 & 639 & 416 \\
2 & Lemak (g) & 8,9 & 23,9 & 13 \\
3 & Protein (g) & 30,7 & 34,4 & 28 \\
4. & Karbohidrat (g) & 49,7 & 71,9 & 47,9 \\
\hline
\end{tabular}

Penentuan komposisi zat gizi dihitung berdasarkan jumlah bahan yang digunakan dan mengacu pada program nutrisurvey. Dari ketiga menu, paket $B$ yang paling tinggi komposisi nilai gizi perporsi kemudian paket $\mathrm{C}$ dan paket $\mathrm{A}$. Dari jumlah kandungan energi dan zat gizi lainnya sudah bisa memenuhi porsi makanan untuk makan pagi yaitu sekitar $1 / 5$ atau $20 \%$ dari total kalori sehari , yang didasarkan pada kecukupan gizi yang dianjurkan bagi anak kelompok usia 712 tahun (Kemenkes 2013).

c. Uji Organoleptik dengan skala hedonik

Dalam menentukan mutu suatu produk, sifat pertama kali yang menentukan diterima atau ditolaknya produk tersebut oleh konsumen adalah sifat organoleptik yang dimiliki seperti penampilan, citarasa, tekstur, warna dan aroma. Untuk mengetahui tingkat kesukaan konsumen terhadap penampilan, citarasa, tekstur, warna dan aroma dilakukan uji organoleptik yaitu dengan uji hedonik. Rentang skala hedonik yang digunakan dalam penelitian ini berkisar dari ekstrim baik sampai ekstrim jelek, dan rentang skala tersebut dapat dilihat pada Tabel 3

Tabel 3. Skala Hedonic

\begin{tabular}{cc}
\hline Skala Hedonik & score \\
Amat sangat suka & 5 \\
Amat suka & 4 \\
Suka & 3 \\
Tidak suka & 2 \\
Amat sangat tidak suka & 1 \\
\hline
\end{tabular}

\section{d. Penampilan}

Berdasarkan hasil uji hedonik yang dilakukan oleh 36 panelis, dapat dilihat bahwa dari parameter penampilan menu yang paling banyak disukai adalah paket $\mathrm{C}$ ada 22 sampel $(61,1 \%)$ dengan nilai rerata 4,4167 atau berada pada skala amat suka 4 dan amat sangat suka 5 . 
Tabel 4. Uji Hedonik Penampilan

\begin{tabular}{cccccccccccc}
\hline & \multicolumn{3}{c}{ Paket A } & \multicolumn{2}{c}{ Paket B } & \multicolumn{2}{c}{ Paket C } & \multicolumn{3}{c}{ MNS1 } & \multicolumn{2}{c}{ MNS2 } \\
\cline { 2 - 11 } Skala Hedonik & $\mathrm{n}$ & \multicolumn{1}{c}{$\mathrm{n}$} & $\%$ & $\mathrm{n}$ & $\%$ & $\mathrm{n}$ & $\%$ & $\mathrm{n}$ & $\%$ \\
& $\%$ & & & & & & & & & \\
\hline Amat sangat & 21 & 58,3 & 20 & 55,6 & 22 & 61,1 & 1 & 2,8 & 4 & 11,1 \\
suka & & & & & & & & & & \\
Amat suka & 9 & 25,0 & 12 & 33,3 & 7 & 19,4 & 7 & 19,4 & 5 & 13,9 \\
$\quad$ Suka & 6 & 16,7 & 4 & 11,1 & 7 & 19,4 & 10 & 27,8 & 17 & 47,2 \\
Tidak suka & 0 & 0 & 0 & 0 & 0 & 0 & 15 & 41,7 & 9 & 25 \\
Amat sangat & 0 & 0 & 0 & 0 & 0 & 0 & 3 & 8,3 & 1 & 2,8 \\
tidak suka & & & & & & & & & & \\
Jumlah & 36 & 100 & 36 & 100 & 36 & 100 & 36 & 100 & 36 & 100 \\
\hline
\end{tabular}

Hasil uji statistic Kruskal Wallis test pada parameter penampilan dengan Mns 1 dan Mns2 terlihat bahwa nilai sig. sampel adalah 0,582 (atau lebih besar dari $=0,05$ ) dan 0,414 (atau lebih besar dari $=0,05$ ) sehingga dapat dinyatakan bahwa pada tingkat kepercayaan $95 \%$, penampilan setiap menu yang diuji tidak berbeda nyata.

e. Cita Rasa

Tabel 5. Uji Hedonik Cita Rasa

\begin{tabular}{cccccccccccc}
\hline & \multicolumn{1}{c}{ Paket A } & \multicolumn{2}{c}{ Paket B } & \multicolumn{2}{c}{ Paket C } & \multicolumn{3}{c}{ MNS1 } & \multicolumn{2}{c}{ MNS2 } \\
\cline { 2 - 11 } Skala Hedonik & $\mathrm{n}$ & \multicolumn{1}{c}{$\mathrm{n}$} & $\%$ & $\mathrm{n}$ & $\%$ & $\mathrm{n}$ & $\%$ & $\mathrm{n}$ & $\%$ \\
& $\%$ & & & & & & & & & \\
\hline Amat sangat & 17 & 47,2 & 18 & 50 & 20 & 55,6 & 8 & 22,2 & 8 & 22,2 \\
$\quad$ suka & & & & & & & & & & \\
Amat suka & 10 & 27,8 & 15 & 41,7 & 7 & 19,4 & 7 & 19,4 & 15 & 41,7 \\
Suka & 9 & 25 & 3 & 8,3 & 9 & 25 & 12 & 33,3 & 11 & 30,6 \\
Tidak suka & 0 & 0 & 0 & 0 & 0 & 0 & 7 & 19,4 & 2 & 5,6 \\
Amat sangat & 0 & 0 & 0 & 0 & 0 & 0 & 2 & 8,3 & 0 & 2,8 \\
tidak suka & & & & & & & & & & \\
Jumlah & 36 & 100 & 36 & 100 & 36 & 100 & 36 & 100 & 36 & 100 \\
\hline
\end{tabular}

Berdasarkan hasil uji hedonik yang dilakukan oleh 36 panelis, dapat dilihat bahwa dari parameter cita rasa menu yang paling banyak disukai adalah Paket C 20 sampel $(55,6 \%)$ dengan nilai rerata 4,3056 atau berada pada skala amat suka 4 dan amat sangat suka 5

Dari table uji statistik Kruskal Wallis test pada parameter cita rasa dengan MNS 1 dan MNS 2 terlihat bahwa nilai sig. sampel adalah 0,421 (atau lebih besar dari $=0,05$ ) dan 0,325 (atau lebih besar dari $=0,05$ ) sehingga dapat dinyatakan bahwa pada tingkat kepercayaan $95 \%$, cita rasa setiap menu yang diuji tidak berbeda nyata. 
e. Tekstur

Berdasarkan hasil uji hedonik yang dilakukan oleh 36 panelis, dapat dilihat bahwa dari parameter tekstur menu yang paling banyak disukai adalah Paket $\mathrm{C}$ dengan nilai rerata 3,722 atau berada pada skala amat suka 4 dan suka 3 .

Tabel 6. Uji Hedonik Tekstur

\begin{tabular}{ccccccccccccc}
\hline & \multicolumn{3}{c}{ Paket A } & \multicolumn{2}{c}{ Paket B } & \multicolumn{2}{c}{ Paket C } & \multicolumn{2}{c}{ Mns1 } & \multicolumn{2}{c}{ Mns2 } \\
\cline { 2 - 11 } Skala Hedonik & $\mathrm{n}$ & \multicolumn{1}{c}{$\mathrm{n}$} & $\%$ & $\mathrm{n}$ & $\%$ & $\mathrm{n}$ & $\%$ & $\mathrm{n}$ & $\%$ \\
& $\%$ & & & & & & & & & \\
\hline Amat sangat & 5 & 13,9 & 7 & 19,4 & 9 & 25 & 7 & 19,4 & 6 & 16,7 \\
$\quad$ suka & & & & & & & & & & \\
Amat suka & 17 & 47,2 & 17 & 47,2 & 17 & 47,2 & 13 & 36,1 & 12 & 33,3 \\
$\quad$ Suka & 13 & 36,1 & 11 & 30,6 & 10 & 27,8 & 15 & 41,7 & 16 & 44,4 \\
Tidak suka & 1 & 2,8 & 1 & 2,8 & 0 & 0 & 0 & 19,4 & 2 & 5,6 \\
Amat sangat & 0 & 0 & 0 & 0 & 0 & 0 & 1 & 2,8 & 0 & 0 \\
tidak suka & & & & & & & & & & \\
Jumlah & 36 & 100 & 36 & 100 & 36 & 100 & 36 & 100 & 36 & 100 \\
\hline
\end{tabular}

Dari table uji statistic Kruskal Wallis test pada parameter tekstur dengan Mns 1 dan Mns2 terlihat bahwa nilai sig. sampel adalah 0,531 (atau lebih besar dari $=0,05$ ) dan 0,05 (atau sama $=0,05$ ) sehingga dapat dinyatakan bahwa pada tingkat kepercayaan $95 \%$, cita rasa setiap menu yang diuji tidak berbeda nyata.

\section{f. Warna}

Tabel 7. Uji Hedonik Warna

\begin{tabular}{|c|c|c|c|c|c|c|c|c|c|c|}
\hline \multirow[b]{2}{*}{ Skala Hedonik } & \multicolumn{2}{|c|}{ Paket A } & \multicolumn{2}{|c|}{ Paket B } & \multicolumn{2}{|c|}{ Paket C } & \multicolumn{2}{|c|}{ Mns1 } & \multicolumn{2}{|c|}{ Mns2 } \\
\hline & $\%^{n}$ & & $\mathrm{n}$ & $\%$ & $\mathrm{n}$ & $\%$ & $\mathrm{n}$ & $\%$ & $\mathrm{n}$ & $\%$ \\
\hline $\begin{array}{c}\text { Amat sangat } \\
\text { suka }\end{array}$ & 9 & 25 & 9 & 25 & 12 & 33,3 & 6 & 16,7 & 3 & 8,4 \\
\hline Amat suka & 12 & 33,3 & 12 & 33,3 & 14 & 38,9 & 9 & 25 & 7 & 19,4 \\
\hline Suka & 12 & 33,3 & 13 & 36,1 & 9 & 25 & 14 & 38,9 & 19 & 52,8 \\
\hline Tidak suka & 3 & 8,4 & 2 & 5,6 & 1 & 2,8 & 2 & 5,6 & 5 & 13,8 \\
\hline $\begin{array}{l}\text { Amat sangat } \\
\text { tidak suka }\end{array}$ & 0 & 0 & 0 & 0 & 0 & 0 & 5 & 13,9 & 2 & 5,6 \\
\hline Jumlah & 36 & 100 & 36 & 100 & 36 & 100 & 36 & 100 & 36 & 100 \\
\hline
\end{tabular}

Berdasarkan hasil uji hedonik yang dilakukan oleh 36 panelis, dapat dilihat bahwa dari parameter warna menu yang paling banyak disukai adalah Paket $C$ dengan jumlah 9 sampel (25\%) dengan nilai rerata 4,02 atau berada pada skala amat suka 4 dan amat sangat suka 5 .

Dari table uji statistic Kruskal Wallis test pada parameter warna dengan Mns 1 dan Mns 2 terlihat bahwa nilai sig. sampel adalah 0,84 (atau lebih besar dari $=0,05$ ) dan 0,736 (atau lebih besar dari $=0,05$ ) sehingga dapat dinyatakan bahwa pada tingkat kepercayaan $95 \%$, warna setiap menu yang diuji tidak berbeda nyata. 


\section{g. Aroma}

Berdasarkan hasil uji hedonik yang dilakukan oleh 36 panelis, dapat dilihat bahwa dari parameter aroma menu yang paling banyak disukai adalah $\mathrm{Mn} 3$ dengan nilai rerata 4,138 atau berada pada skala amat suka 4 dan amat sangat suka 5

Tabel 8. Uji hedonic Aroma

\begin{tabular}{cccccccccccc}
\hline & \multicolumn{2}{c}{ Paket A } & \multicolumn{2}{c}{ Paket B } & \multicolumn{2}{c}{ Paket C } & \multicolumn{2}{c}{ Mns1 } & \multicolumn{2}{c}{ Mns2 } \\
\cline { 2 - 11 } Skala Hedonik & \multicolumn{2}{c}{$\mathrm{n}$} & & $\mathrm{n}$ & $\%$ & $\mathrm{n}$ & $\%$ & $\mathrm{n}$ & $\%$ & $\mathrm{n}$ & $\%$ \\
& $\%$ & & & & & & & & & \\
\hline Amat sangat & 10 & 27,8 & 9 & 25 & 16 & 44,4 & 7 & 19,4 & 5 & 13,9 \\
suka & & & & & & & & & & \\
Amat suka & 13 & 36,1 & 14 & 38,9 & 10 & 27,8 & 11 & 30,6 & 17 & 47,2 \\
Suka & 13 & 36,1 & 12 & 33.3 & 9 & 25 & 15 & 41,7 & 9 & 25 \\
Tidak suka & 0 & 0 & 1 & 2,8 & 1 & 2,8 & 3 & 8,3 & 4 & 11,1 \\
Amat sangat & 0 & 0 & 0 & 0 & 0 & 0 & 0 & 0 & 1 & 2,8 \\
tidak suka & & & & & & & & & & \\
Jumlah & 36 & 100 & 36 & 100 & 36 & 100 & 36 & 100 & 36 & 100 \\
\hline
\end{tabular}

Dari table uji statistic Kruskal Wallis test pada parameter aroma dengan Mns 1 dan Mns2 terlihat bahwa nilai sig. sampel adalah 0,291 (atau lebih besar dari $=0,05$ ) dan 0,630 (atau lebih besar dari $=0,05$ ) sehingga dapat dinyatakan bahwa pada tingkatkepercayaan $95 \%$, cita aroma menu yang diuji tidak berbeda nyata.

h. Nilai Rerata Uji Hedonik

Tabel 9. Rerata uji Hedonik

\begin{tabular}{lccc}
\hline \multicolumn{1}{c}{ Penilaian } & Paket A & Paket B & Paket C \\
\hline Penampilan & 4,4 & 4,4 & 4,4 \\
Cita rasa & 4,2 & 4,4 & 4,3 \\
Tekstur & 3,7 & 3,8 & 3,9 \\
Warna & 3,7 & 3,7 & 4,2 \\
Aroma & 3,9 & 4,0 & 4,2 \\
\hline Rata-Rata & 3,98 & 4,02 & 4,18
\end{tabular}

Dari keseluruhan parameter penilaian paket $\mathrm{C}$ memiliki Nilai rerata yang paling tinggi, tetapi jika dilihat dari rerata masing-masing menu semuanya berada dalam kategori suka (3) sampai sangat suka (4). Dapat disimpulkan ketiga menu tersebut disukai konsumen secara statistik tidak ada perbedaan.

\section{PEMBAHASAN}

Berdasarkan karakteristik subjek penelitian menunjukkan bahwa jumlah responden 36 orang siswa, yang terdiri dari 29 orang siswa kelas 5 dan 7 orang siswa kelas 6, dengan jenis kelamin terdiri dari laki-laki 14 orang siswa dan perempuan 22 orang siswa. Golongan 10-12 tahun merupakan golongan usia siswa yang duduk di kelas 5 dan 6 . Mereka pada umumnya bisa menentukan 
makanan yang disukai karena mereka sudah mengenal lingkungan, untuk itu perlu pengawasan orang tua supaya tidak salah dalam memilih makanan karena pengaruh lingkungan (Judarwanto, 2009)

Sarapan pagi bagi anak sekolah sangatlah penting, karena waktu sekolah adalah penuh aktifitas yang membutuhkan energy dan kalori yang cukup besar. Untuk sarapan pagi bagi anak membutuhkan 1/4 kalori sehari (Judarwanto, 2009). Berdasarkan hasil penelitian untuk penentuan komposisi zat gizi dari ketiga paket menu $A, B$ dan $C$, ternyata menu paket $B$ yang memiliki komposisi zat gizi tertinggi baik jumlah Kalori, Protein, Lemak maupun Karbohidrat, yang dihitung berdasarkan jumlah bahan yang digunakan dan mengacu pada program nutrisurvey. Menu breakfast merupakan salah satu pesan dalan Pedoman Umum Gizi Seimbang yang dapat menyumbang 450-500 kalori dengan 8-9 gram protein (Muhilal dan Damayanti, 2006) Apabila dibandingkan dengan DKGA untuk anak usia 10-12 tahun untuk kecukupam Energi, Protein, Lemak dan Karbohidrat, maka Menu paket B yang tepat untuk menjadi menu breakfast bagi anak usia sekolah agar terhindar dari masalah gizi kurang yang dapat menyebabkan anak mudah lelah, tidak tahan melakukan aktifitas fisik yang lama, tidak mampu berpikir dan berpartisipasi penuh dalam proses belajar.

Dalam penelitian ini penampilan menu juga sangat diperhatikan. Salah satu permasalahan yang sering dikeluhkan orang tua ketika memiliki anak usia pertumbuhan adalah anak susah makan sehingga menimbulkan kekhawatiran bagi orang tua akan asupan gizi yang masuk ke dalam tubuh anak. Dalam penelitian ini penampilan juga sangat diperhatikan. Oleh sebab itu untuk menilai penampilan menu meggunakan Uji Organoleptik dengan skala hedonik. Dan rentang skala hedonik berkisar dari ekstrim baik sampai ekstrim jelek. Hasil uji hedonik untuk penampilan dari menu breakfast $A, B$,dan $C$ oleh 36 panelis ternyata yang paling banyak di sukai dari segi penampilan menu oleh panelis untuk adalah menu C. Ini dibuktikan dengan nilai rerata dari menu 3 adalah 4.4167 atau berada pada skala amat suka 4 dan skala amat sangat suka 5 .

Selanjutnya pada table uji statistic Kruskal Wallis test pada parameter penampilan mns 1 menunjukkan nilai sig sampel adalah 0.582 (lebih besar dari = $0,05)$ yang berarti tidak ada perbedaan dengan menu yang lain. Begitu juga halnya dengan Mns 2 nampak bahwa nilai sig. sampel adalah 0.414 (lebih besar dari $=0.05$ ) sehingga dinyatakan bahwa pada tingkat a kepercayaan $95 \%$, penampilan setiap menu yang diuji tidak berbeda nyata. Hasil ini menunjukkan bahwa penampilan menu breakfast untuk menu sekolah (Mns) 1 dan menu sekolah (Mns) 2 yang disajikan dalam penelitian ini sama. Salah satu cara untuk membuat anak suka makan makanan yang disajikan adalah menyajikan makanan dengan penampilan yang menarik dan bervariasi.

Ungkapan"look good enough for food" bukanlah suatu ungkapan yang berlebihan. Makanan harus baik dilihat saat berada di piring, dimana hal tersebut adalah salah satu faktor terpenting. Kesegaran dan kebersihan dari makanan yang disajikan adalah contoh penting yang akan mempengaruhi penampilan makanan baik atau tidak untuk dinikmati.

Dari segi rasa menu yang paling banyak disukai adalah paket menu $\mathrm{C}$ dengan nilai rerata 4,3056 berdasarkan uji mutu hedonik, dan berada pada skala amat suka dan sangat suka. Berbeda dengan uji statistik Kruskal Wallis test pada 
parameter cita rasa dengan Mns 1 terlihat bahwa nilai sig. sampel adalah 0,421 (atau lebih besar dari $=0,05$ ) sehingga dapat dinyatakan bahwa pada tingkat $\alpha$ kepercayaan 95\%, cita rasa setiap menu yang diuji tidak berbeda nyata. Kemudian dari table uji statistic Kruskal Wallis test pada parameter cita rasa dengan Mns 2 terlihat bahwa nilai sig. sampel adalah 0,325 (atau lebih besar dari $=0,05$ ) sehingga dapat dinyatakan bahwa pada tingkat a kepercayaan 95\%, cita rasa setiap menu yang diuji tidak berbeda nyata. Hasil uji cita rasa ini menunjukkan bahwa semua menu mempunyai cita rasa yang sama. Cita rasa adalah suatu cara pemilihan makanan yang dibedakan dari rasa (taste) makanan tersebut. Cita rasa merupakan atribut makanan yang meliputi bau, rasa, tekstur dan suhu (Drummond \& Brefere,2010).

Tekstur atau konsistensi makanan yang dihidangkan hendaknya disesuaikan dengan kemampuan fisiologis dan juga umur. Berdasarkan hasil uji hedonik tekstur paket menu yang paling banyak disukai adalah menu C (3) dengan nilai rerata 3,722 atau berada pada skala amat suka 4 dan suka 3 . Penilaian tekstur makanan dapat dilakukan dengan jari, gigi, dan langit-langit (palatum). Dari nilai yang diperoleh diharapkan dapat diketahui kualitas makanan.Faktor tekstur diantaranya adalah rabaan oleh tangan, keempukan, kemudahan dikunyah serta kerenyahan makanan. Untuk itu cara pemasakan bahan makanan dapatmempengaruhi kualitas tekstur makanan yang dihasilkan.

Selanjutnya pada uji statistic Kruskal Wallis untuk parameter tekstur dengan Menu sekolah (Mns) 1 terlihat bahwa nilai sig. sampel adalah 0,531 (atau lebih besar dari $=0,05$ ) sehingga dapat dinyatakan bahwa pada tingkat $\alpha$ kepercayaan $95 \%$, tekstur setiap menu yang diuji tidak berbeda nyata. Berbeda dengan menu sekolah (Mns) 2 nilai sig. sampel adalah 0.05 (atau sama $=0.05$ ) sehingga dinyatakan pada tingkat a kepercayaan 95\%, tekstur setiap menu yang diuji berbeda nyata. Artinya ada perbedaan antara menu sekolah 2 dengan paket menu yang lain. Warna

Berdasarkan uji kesukaan dengan menggunakan skala hedonic terhadap warna ternyata Paket menu $\mathrm{C}$ yang banyak disukai dimana responden yang menyatakan amat sangat suka 9 orang siswa, amat suka 12 orang siswa dan suka 13 orang siswa. Akan tetapi setelah diuji dengan uji statistic Kruskal Wallis test untuk parameter warna menu sekolah (Mns) 1 diperoleh nilai sig. sampel adalah 0.84 (atau lebih besar dari 0.05). Hasil ini menunjukkan bahwa setiap warna menu yang diuji tidak berbeda nyata. Demikian juga halnya dengan menu sekolah (Mns) 2 setelah diuji dengan menggunakan uji Kruskal Wallis menunjukkan bahwa warna menu yang diuji tidak berbeda nyata.

Warna makanan memiliki peranan utama dalam penampilan makanan,meskipun makanan tersebut lezat, tetapi bila penampilan tidak menarik waktu disajikan akan mengakibatkan selera orang yang akan memakannya menjadi hilang.Warna biasanya merupakan tanda kemasakan atau kerusakan dari makanan, seperti perlakuan penyimpanan yang memungkinkan adanya perubahan warna. Oleh karenaitu untuk mendapatkan warna yang sesuai dan menarik harus digunakan tehnik memasak tertentu atau dengan penyimpanan yang baik (Meilgard, dkk.2000)

Aroma adalah bau yang sangat subyektif serta sulit diukur, karena setiap orang mempunyai sensitifitas dan kesukaan yang berbeda. Meskipun mereka dapat mendeteksi, tetapi setiap individu memiliki kesukaan yang berlainan. 
Berdasarkan hasil uji hedonik yang dilakukan oleh 36 panelis, dapat dilihat bahwa dari parameter aroma menu yang paling banyak disukai adalah $\mathrm{Mn} 3$ dengan nilai rerata 4,138 atau berada pada skala amat suka 4 dan amat sangat suka 5 . Timbulnya aroma makanan disebabkan oleh terbentuknya senyawa yang mudah menguap. Aroma yang dikeluarkan setiap makanan berbeda-beda. Selain itu,cara memasak yang berbeda akan menimbulkan aroma yang berbeda pula. Rasa makanan merupakan faktor kedua yang mempengaruhi citarasa makanan setelah penampilan makanan itu sendiri (Meilgaard, dkk.2000)

Dari table uji statistic Kruskal Wallis test pada parameter aroma dengan menu sekolah (Mns) 1 terlihat bahwa nilai sig. sampel adalah 0,291 (atau lebih besar dari $=0,05$ ) sehingga dapat dinyatakan bahwa pada tingkat $\alpha$ kepercayaan $95 \%$, aroma menu yang diuji tidak berbeda nyata. Selanjutnya untuk uji statistic Kruskal Wallis test pada parameter aroma dengan menu sekolag (Mns) 2 terlihat bahwa nilai sig. sampel adalah 0,630 (atau lebih besar dari $=0,05$ ) sehingga dapat dinyatakan bahwa pada tingkat a kepercayaan 95\%, aroma setiap menu yang diuji tidak berbeda nyata. Timbulnya aroma makanan disebabkan oleh terbentuknya senyawa yang mudah menguap. Aroma yang dikeluarkan setiap makanan berbeda-beda. Selain itu,cara memasak yang berbeda akan menimbulkan aroma yang berbeda pula. Rasa makanan merupakan faktor kedua yang mempengaruhi citarasa makanan setelah penampilan makanan itu sendiri.

\section{KESIMPULAN DAN SARAN \\ Simpulan}

1. Menu paket ubi berwarna dengan komposisi nilai gizi energi 399 Kalori; protein 30,7 gram; lemak 8,9 gram; kharbohidrat 49,7 gram.

2. Menu paket singkong goreng gurih dengan komposisi nilai gizi energi 639 Kalori; protein 34,4 gram; lemak 23,9 gram; kharbohidrat 71,9 gram.

3. Menu paket steak kentang rebus dengan komposisi nilai gizi energi 416 Kalori; proten 28 gram; lemak 13 gram ; kharbohidrat 47 gram.

4. Secara statistik tidak ada perbedaan nyata antara ketiga menu breakfast dengan menu konvensional, namun berdasarkan nilai rata-rata dari skor hedonik terdapat perbedaan.

\section{Saran}

Menu breakfast pangan lokal dapat dijadikan acuan dalam upaya meningkatkan asupan zat gizi dan untuk membiasakan anak sekolah sarapan pagi dengan menu yang seimbang.

\section{DAFTAR PUSTAKA}

Depkes R.I.,2004. Analisis Situasi Gizi \& Kesehatan Masyarakat. Direktorat Jenderal Bina Kesehatan Masyarakat. Direktorat Gizi Masyarakat. Jakarta.

Syafruddin, Sutjahjo, S.H., Baliwati, Y.F., Nurmalita.R. (2007) Starategi Pengelolaan dan Analisis Status Keberlanjutan Ketahanan Pangan di Kabupaten Halmahera Tengah.Jurnal Pengkajian dan Pengembangan Teknologi Pertanian. 10(1) Juni, pp. 30-38.

Gail C. Rampersaud., Marka A.Pereira.,Beverly L.Girard.,Judi Adams.,Jordan D.Metzl.,(2005).Breakfast Habits, Nutritional Status, Body Weight, anda 
Academic Performance in children and adolecents., Journal of The American Dietetic Association, 743 - 760

Watanabe, K., Flores, R., Fujiwara, J., \& Tran, L. (2005) Early Childhood Development Intervention and Cognitive Development of Young Children in Rural Vietnam. J.Nutr, 1918-1925.

Khomsan, A. (2003) Pangan dan Gizi untuk Kesehatan. Raja Grafindo Persada, Jakarta.

Sukati Saidin, Y., Krisdinamurtirin., Ance Murdiana., Moecherdiyatiningsih

Moecherdiyatiningsih., Lies Darwin Karyadi., Sri Murni.Hubungan

Kebiasaan Makan dengan Konsentrasi Belajar. Jurnal Penelitian Gizi dan

Makanan, 60 - 73

Kurniasari, R. (2005) Hubungan Frekuensi dan Asupan Gizi Makan Pagi dengan Kadar Hemoglobin ( $\mathrm{Hb})$ Darah dan Konsentrasi di Sekolah pada Murid Kelas V dan VI SDN Jetis I dan SDN Jetishardjo I Yogyakarta. Tesis Pasca Sarjana Program Studi IKM Minat Utama Gizi Kesehatan, UGM, Yogyakarta.

Sobaler, A.M.L., Ortega, R.M., Quintas, M.E., Navia, B. \& Requejo, A.M. (2003). Relationship between Habitual Breakfast and Intellectual Performance (Logical Reasoning in Well-Nourished Schoolchildren of Madrid (Spain). European Journal of Clinical Nutrition, Suppl 1, S49-S53.

Soekirman. (2000) IImu Gizi dan Aplikasinya. Dirjen Dikti Depdiknas RI, Jakarta

Soekirman (2004) Perlu Paradigma Baru untuk Menanggulangi Masalah Gizi Makro di Indonesia, http:www.gizinet. (Diakses 12 Pebruari 2015)

Linder, M.C. (2006) Biokimia Nutrisi dan Metabolisme dengan Pemakaian secara Klinis (Parakkasi, A.; penerjemah). UI Press, Jakarta.

Apriyantono, A. (2005) Revitalisasi Pertahanan dan Pemantapan Ketahanan Pangan Rumah Tangga. In: Sandjaya, Sumarno, I., Soekatri, M., Sofia, G., Kusindrati, Hartati, B.S.A., Kresnawan, T., Nursanyoto, H. \& Sudikno. ed. Prosiding Temu Ilmiah, Kongres PERSAGI XIII dan Festival Gizi, November 20-24, 2005, Grand Inna, Bali Beach, Sanur-Bali. Dewan Pimpinan Pusat Persatuan Ahli Gizi Indonesia (PERSAGI)., pp.11-20

Sophia, E (2014) Maksimalkan Potensi Anak dan Bayi.[Internet], Available from: http://medicastore.com/ [Accessed 6 November 2014)

Andarwati,R. Prawirohartono,E.P. \& Gamayanti,I.L. (2006) Hubungan Berat Badan Lahir, Pemberian ASI Eksklusif, Status Gizi Dan Stimulasi Kognitif Dengan Kecerdasan Anak Usia 5-6 Tahun. Jurnal Gizi Klinik Indonesia, 2 (3), 95100.

Almatsier, S. (2004) Prinsip Dasar Ilmu Gizi. PT Gramedia Pustaka Utama, Jakarta.

Sekretariat Negara, 2009. Peraturan Presiden Nomor 22 tahun 2009 tentang Kebijakan Percepatan Penganekaragaman Konsumsi Pangan Berbasis Sumber Daya Lokal

Kartika,B. 1988.,Pedoman Uji Inderawi Bahan Pangan Yogyakarta; Pusat Antar Universitas Pangan dan Gizi UGM.

Drummond, K.E., \& Brefere, L.M. (2010) Nutrition for food service and culinary professionals., New Jersey; John Wiley \& Sons, Inc

Soekarto, S. 1990. Dasar-Dasar Pengawasan dan Standarisasi Mutu Pangan IPBPress, Bogor. 
Meilgaard, M., Civille G.V., Carr B.T. Sensory Evaluation Techniques. Boca Raton, Florida: CRC Press; 2000

Judarwanto, W. 2008. Perilaku Makan Anak Sekolah. http://ludruk.com Muhilal \& Damayanti, D. (2006) Gizi seimbang untuk anak usia sekolah dasar. In : Soekirman, Susana, H., Giarno, M.H. \& Lestari Y. eds. Hidup sehat: Gizi seimbang dalam siklus Kehidupan Manusia: Primamedia Pustaka. 